\title{
PREVALENCE AND CHARACTERISTICS OF PALATINE TONSILLOLITHS IN CONE BEAM COMPUTED TOMOGRAPHY IMAGES: A RETROSPECTIVE STUDY
}

\author{
Konik Işınlı Bilgisayarlı Tomografi Görüntülerinde Palatin Tonsillolitin Prevelans ve Özellikleri: \\ Retrospektif Bir Çalışma
}

\author{
Kemal Özgür DEMIRALP1, Seval BAYRAK² ${ }^{2}$ Emine Şebnem KURŞUN ÇAKMAK \\ ${ }^{l}$ DDS, PhD. Ministry of Health, Türkiye Public Hospitals Agency, ANKARA, TÜRKIYE \\ ${ }^{2}$ Abant İzet Baysal University, Dentistry Faculty, Dentomaxillofacial Radiology Department, BOLU, TÜRKIYYE
}

Introduction: Palatine tonsilloliths are calcified structures that develop in enlarged tonsillar crypts. These structures are also common incidental findings that can be clinically related to halitosis and tonsillar abscess. The aim of this study is to clarify the prevalence and imaging characteristics of palatine tonsilloliths by using Cone Beam Computed Tomography (CBCT).

Material and Methods: Three hundred and sixty-six CBCT scans were retrospectively evaluated with regard to presence and characteristics of tonsilloliths.

Results: Palatine tonsilloliths' detection rate was found $20.4 \%$ without statistically significant gender prediliction $(56 \%$ in female, $44 \%$ in male patients). The mean age of tonsilloliths patients was 33.3 years. The size of the tonsilloliths ranged from $0.3 \mathrm{~mm}$ to 5 $\mathrm{mm}$. No statistically significant difference between the left and right sides was detected with regard to tonsilloliths presence.

Conclusion: Palatine tonsilloliths are common forms of soft tissue calcifications. CBCT is a very helpful imaging modality in identifying the true location of tonsilloliths.
Giriș: Palatin tonsillolitler genișlemiş olan tonsiller kriptalarında gelişen kalsifiye yapılardır. Bu yapılar aynı zamanda halitozis ve tonsiller abse ile klinik olarak ilişkili olabilen rastlantısal bulgulardır. Bu çalışmanın amacı Konik Işınlı Bilgisayarlı Tomografi (KIBT) kullanarak palatin tonsillolitlerin prevelansını ve radyolojik özelliklerini göstermektir.

Gereç ve Yöntem: 366 adet KIBT görüntüsü tonsillolit varlığ ve özellikleri açısından retrospektif olarak değerlendirilmiştir.

Bulgular: Palatin tonsillolit \%20,4 oranında izlenirken istatistiksel olarak cinsiyet açısından herhangi bir fark izlenmemiştir (\%56 kadın, \%44 erkek). Tonsillolit izlenen hastaların ortalama yaşı 33,3 'tür. Tonsillolitlerin boyutu $0,3 \mathrm{~mm}$ ile $5 \mathrm{~mm}$ arasındadır. Tonsillolit varlığ 1 bakımından sol ve sağ taraf için istatistiksel olarak bir fark saptanmamıştır.

Sonuç: Palatin tonsillolitler yumuşak doku kalsifikasyonlarının sık görülen türleridir. Konik Işınlı Bilgisayarlı Tomografi, tonsillolitlerin gerçek yerinin tespitinde oldukça yardımcı bir görüntüleme yöntemidir.

Anahtar Kelimeler: Tonsillolit, bademcik taşı, Konik Işınlı Bilgisayarlı Tomografi, palatin tonsil 


\section{INTRODUCTION}

Palatine tonsils, pharyngeal tonsils (the adenoids) and lingual tonsils are three major groups of tonsils and generates a discontinuous ring to form Waldeyer's ring (1). Tonsilloliths are unusual calcified concretions that originates in tonsillar crypts within the substance of the tonsil or around it (2). Dystrophic calcifications may cause tonsilloliths despite normal serum calcium and phosphate levels. The mechanism of these calcifications is still contradictive, though they appear to result from the accumulation of material retained within the tonsillar crypts, accompanied by the growth of bacteria and fungi- sometimes related to persistent chronic purulent tonsillitis (3-5).

Palatine tonsilloliths are usually in asymptomatic nature. In fact, they may be discovered incidentally on routine panoramic radiographs, which are taken during dental treatment $(6,7)$. Large palatine tonsilloliths can cause recurrent or persistent throat irritations or discomfort, pain, dysphagia, bad taste, odor, otalgia, and foreign body sensation noted on swallowing $(6,7)$. Palatine tonsilloliths are also suspected to be a causative factor of orofacial pain or glossopharyngeal neuralgia (8).

For clinicians, discrimination of palatine tonsilloliths from pathological calcified structures like sialoliths of parotid and submandibular glands is essential. But, the prevalence and imaging characteristics of tonsilloliths in panoramic radiographs are still unclear, and there is no clue for differential diagnosis by panoramic radiography alone (7). CBCT is being widely used in recent years with high resolution and low-dose radiation in dentomaxillofacial radiology. This technology can also serve as a valuable diagnostic tool for the localization of soft tissue calcifications by oral and maxillofacial radiologists (9).

The aim of this study is to clarify the prevalence, age and gender predilection and imaging characteristics of palatine tonsilloliths on CBCT images.

\section{MATERIALS AND METHODS}

We designed a retropective study consisting of images of 366 patients (150 male, 216 female) who visited Abant İzzet Baysal University, Dentistry Faculty between the years 2014 and 2016. Scans involving oro/nasopharynx were reviewed searching for calcifications within the region of the palatine tonsils. The CBCT scans had been prescribed for various reasons such as implant planning, third molar extraction, orthodontic treatment etc. None of the CBCT scans in the present study were prescribed for reasons involving the presence of tonsilloliths. The age of study population ranged from 7 to 88 years, with a mean age of 34.7 years. The CBCT examinations were divided into four groups according to the patients' ages: younger than 35 years; $35-50$ years; $50-65$ years; older than 65 years. The characteristics of tonsilloliths were compared among these groups. Images with poor image quality and unsuitable field of view for detection of tonsilloliths were excluded. Thirty four images were excluded from the study because of the insufficient diagnostic criteria.

CBCT scans were obtained using I-Cat (Imaging Sciences International, Hatfield, PA, USA). All of the images were evaluated by the same investigator with an experience of 10 years in Dentomaxillofacial Radiology. $0.2 \mathrm{~mm}$ slices in the axial planes, $1 \mathrm{~mm}$ slices in sagittal planes, $1 \mathrm{~mm}$ slices in coronal planes and if necessary panoramic images were reconstructed for each image. $120 \mathrm{kVp}, 15 \mathrm{~mA}, 16 \times 7 \mathrm{~mm}$ FOV were imaging parameters. The images with calcification (Figure 1,2) were evaluated according to age, gender, location (unilateral or bilateral), size and form (soliter or multiple). For calibration and evaluation of intraexaminer reliability randomly selected $20 \mathrm{CBCT}$ images were measured twice with 10 days interval. All measurements were repeated after 2 weeks by the same investigator, and the mean of the 2 measurements was used in the statistical analysis. Chi-square test with a significance level of $5 \%$ was used to determine statistical significance. An independent- t test was used 
for comparing the age groups to confirm the presence

of tonsilloliths.

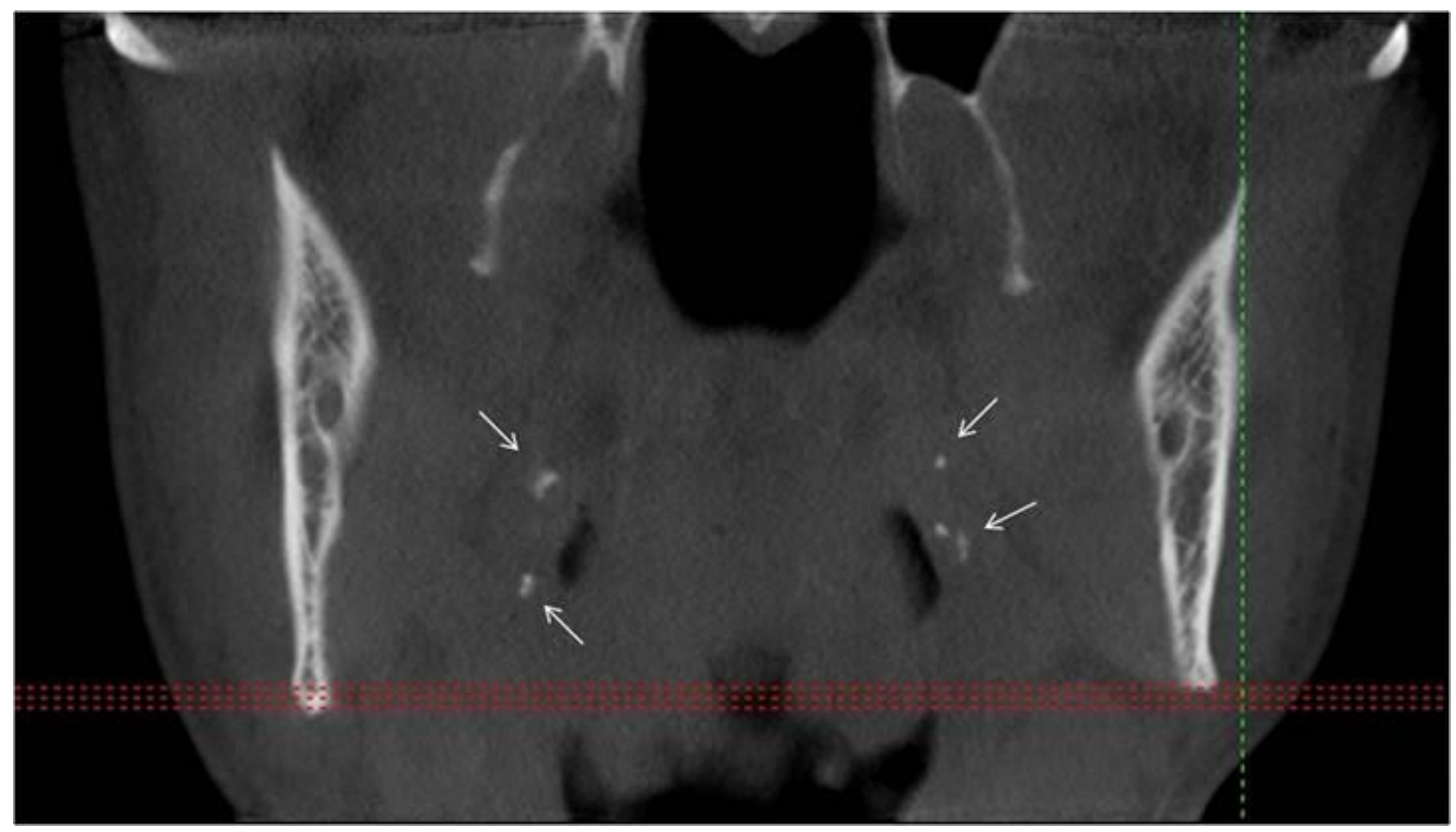

Figure 1. Multiple palatinal tonsilloliths are shown with arrows in coronal CBCT image

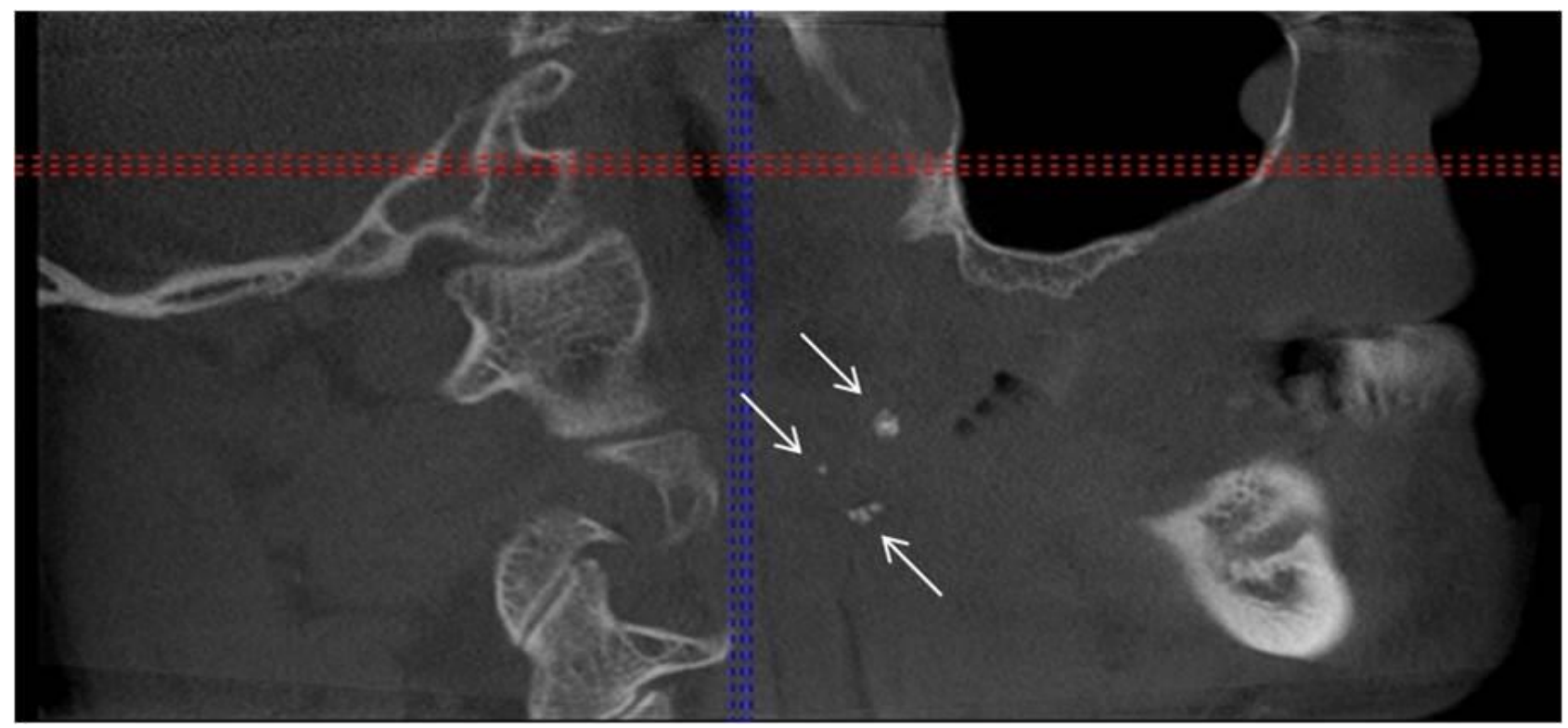

Figure 2. Multiple palatinal tonsilloliths are shown with arrows in sagittal CBCT image 


\section{RESULTS}

The systemic intra-examiner error was evaluated at $p$ $<0.05$ and found to be statistically insignificant. Palatine tonsilloliths were present in 75 cases $(20.4 \%)$ with a ratio of $56 \%$ in female patients and $44 \%$ in male patients $(p \geq 0.05)$.

Calcification characteristics of cases are given in Table 1. The mean age of calcification detected patients was 33.3 years. There was no statistically significant relationship between the age groups and the presence of calcification. $(p \geq 0.05)$. In Table 2 , detailed age distribution of patients having tonsilloliths are given.

The linear size measurement of palatine calcifications in $\mathrm{mm}$ ranged between $0.3 \mathrm{~mm}$ to $5 \mathrm{~mm}$, with a mean size of $2.42 \mathrm{~mm}$. There was no statistically significant difference between the left and right sides regarding the presence and size of tonsilloliths ( $p \geq 0.05$ ).

Table 1. Detailed characteristics of tonsilloliths

\begin{tabular}{|c|c|c|c|c|c|c|c|}
\hline \multicolumn{2}{|c|}{ Gender (\%) } & \multicolumn{2}{|c|}{ Location (\%) } & \multicolumn{2}{|c|}{ Form (\%) } & \multicolumn{2}{|c|}{ Size $(\mathrm{mm})$} \\
\hline Male & Female & Unilateral & Bilateral & Soliter & Multiple & Left & Right \\
\hline $33(44)$ & $42(56)$ & $50(66.7)$ & $25(33.3)$ & $38(50.7)$ & $37(49.3)$ & 2.9 & 2.01 \\
\hline \multirow[t]{2}{*}{-} & - & Left Right & - & - & Left Right & - & - \\
\hline & & $24(48) 26(52$ & - & - & $7(46) 20(54)$ & - & - \\
\hline
\end{tabular}

Table 2. Age distribution of palatine tonsillits

\begin{tabular}{|l|l|l|}
\hline Age (years) & Frequency & Percent (\%) \\
\hline $35-50$ & 28 & 24 \\
\hline $50-65$ & 19 & 25.4 \\
\hline$>65$ & 17 & 22.6 \\
\hline Total & 75 & 100 \\
\hline
\end{tabular}

\section{DISCUSSION}

Palatine tonsilloliths are common incidental findings that can be clinically related to halitosis and tonsillar abscess. A study carried out by Stoodley et al. stated a connection between tonsilloliths and halitosis in patients with a certain type of recurrent tonsillitis (10). The clinical and imaging findings of tonsilloliths depend on the size of these structures; inframilimetric calcifications principally are not visible by imaging and usually asymptomatic. Small tonsilloliths (1 to $7 \mathrm{~mm}$ ) are visible by imaging and the big ones that are superior of $7 \mathrm{~mm}$ are extraordinary structures and mostly symptomatic (11). Mesolella et al, found tonsilloliths in the tonsillar fossa, tonsillar tissue and palatine with the ratio of $21.2 \%, 69.7 \%, 9 \%$, respectively. Mesolella et al. also stated that these entities ranged between a few milimetres to several centimeters in size (12). Takahashi et al. estimated that the tonsillolith's prevalence increased with age, and most commonly in patients who are 50 to 69 years old (13). They stated that the prevalence in the 30s and younger patients was statistically lower than in the $40 \mathrm{~s}$ and older patients. The researchers also numbered the tonsilloliths per palatine between 1 to 18 and found the size to be between 1 to $10 \mathrm{~mm}$. In the current study, the size of palatine calcifications were found between 0.3 to $5 \mathrm{~mm}$, in line with Takahashi et al (13). Caldas et al. observed that tonsilloliths occur more frequently in adults than in children, most commonly between 20 to 68 years with no gender predilection. The mean age of calcification was found 33.3 years in this study in parallel with Caldas et al (14). Pruet and Duplan reported that tonsilloliths can occur at any age, but the occurrence of palatine tonsilloliths in children is unusual (6). They are most frequently detected in the fourth decade of life. No predilection for gender has been reported by Pruet and Duplan similar to that 
reported by our study (6). Our investigation showed no statistically significant differencen between males and females concerning the formation of tonsilloliths.

Tonsilloliths were detected in $300(13.4 \%)$ and 914 (40.7\%) of the 2244 individuals on panoramic radiographs and $\mathrm{CT}$, respectively in the Takahashi et al study (15). In the present study on CBCT images, the prevalence of palatine tonsil calcifications was $20.4 \%$, which was higher than that reported by Aspestrand and Kolbenstvedt (16\%) and lower than Fauroux et al (24.6\%) on CT scans $(16,17)$.

Small tonsilloliths remain undetected due to the partial volume effect caused by the thicker reconstruction thickness (5-10 mm) of CT images (13). In comparison to $\mathrm{CT}$, CBCT offers the advantages of significantly thiner slice thickness and a more compact design with sufficient accuracy (18). Tonsilloliths can be detected via clinical diagnosis, physical investigation and radiological observation. In physical investigation, if there is enlargement and hardening of tonsil, the clinician must suspect tonsilloliths. On extraoral radiographs, a tonsillolith produces a radiopaque shadow that may be mistaken for different calcified entities. Two dimensional radiographs such as panoramic radiography fails in the detection of exact localization of soft-tissue calcifications adjacent to bone. Differentiation of these calcifications can be made easily by 3 dimensional imaging modalities such as CBCT (18). There are limited number of studies on CBCT evaluation of soft tissue calcifications such as tonsillar calcifications.

Palatine tonsilloliths were common forms of calcification in the soft tissue. While CBCT is very helpful imaging modality in identifying the true location of tonsilloliths, the routine use of these devices is not recommended because of the higher radiation dose compared with conventional systems. CBCT should only be used when the clinical question cannot be answered by conventional radiography. Gender and age is an independent variable to on the formation of palatine tonsil calcifications.

\section{REFERENCES}

1. Kajan ZD, Sigaroudi AK, Mohebbi M. Prevalence and patterns of palatine and adenoid tonsilloliths in cone-beam computed tomography images of an Iranian population. Dent Res J. 2016; 13(4): 31521.

2. Chan J, Rashid M, Karagama Y. An unusual case of a tonsillolith. Case Rep Med. 2012; 2012: 587503.

3. Silvestre Donat FJ, Mocholi AP, Estelles Ferriol E, Martinez Mihi V. Giant tonsillolith: report of a case. Med Oral Patol Oral Cir Bucal. 2005; 10(3): 239-42.

4. Moura MD, Madureira DF, Noman-Ferreira LC, Abdo EN, Aquiar EG, Freire AR. Tonsillolith: a report of three clinical cases. Medicina Oral, Patologia Oral y Cirugia Bucal. 2007; 12(2): 130-3.

5. Cakur B, Yildirim E, Demirtas O. An investigation of relationship between tonsillolith and carotid artery calcification on panoramic radiography. Ataturk Univ Dis Hek Fak Derg. 2014; 24(1): 1-5.

6. Pruet CW, Duplan DA. Tonsil concretions and tonsilloliths. Otolaryngol Clin North Am. 1987; 20(2): 305-9.

7. Mandel L. Multiple bilateral tonsilloliths: case report. J Oral Maxillofac Surg. 2008; 66(1): 148-50.

8. Siber S, Hat J, Brakus I, et al. Tonsillolithiasis and orofacial pain. Gerodontology. 2012; 29 (2): 115760.

9. Howerton WB Jr, Mora MA. Use of cone beam computed tomography in dentistry. Gen Dent. 2007; 55(1): 54-7.

10. Stoodley P, Debeer D, Longwell $M$, et al. Tonsillolith: not just a stone but a living biofilm. Otolaryngol Head Neck Surg. 2009; 141(3): 31621.

11. Yousef H, Hazem Y, Omar M, Ahmad M, Farghaly TM. Tonsillar calcification, computed tomography and clinical findings, a case study. Med J Cairo Univ. 2012; 80(1): 427-34. 
12. Mesolella M, Cimmino M, Martino MD, Criscuoli G, Albanese L, Galli V. Tonsillolith: case report and review of the literature. Acta Otorhinolaryngol Ital. 2004; 24(5): 302-7.

13. Takahashi A, Sugawara C, Kudoh T, et al. Prevalence and imaging characteristics of palatine tonsilloliths detected by $\mathrm{CT}$ in 2,873 consecutive patients. Scientific World Journal. 2014; 2014: 940960 .

14. Caldas MP, Neves EG, Manzi FR, De Almeida SM, Boscolo FN, Haiter-Neto F. Tonsillolith: report of an unusual case. British Dental Journal. 2007; 202(5): 265-7.

15. Takahashi A, Sugawara C, Kudoh T, et al. Prevalence and imaging characteristics of palatine tonsilloliths evaluated on 2244 pairs of panoramic radiographs and $\mathrm{CT}$ images. Clin Oral Investig. 2017; 21(1): 85-91.

16. Aspestrand F, Kolbenstvedt A. Calcifications of the palatine tonsillary region: CT demonstration. Radiology. 1987; 165: 479-80.

17. Fauroux MA, Mas C, Tramini P, Torres JH. Prevalence of palatine tonsilloliths: A retrospective study on 150 consecutive CT examinations. Dentomaxillofac Radiol. 2013; 42: 201-4.

18. Misirlioglu M, Nalcaci R, Adisen MZ, Yardımci S. Bilateral and pseudobilateral tonsilloliths: Three dimensional imaging with cone-beam computed tomography. Imaging Science in Dentistry. 2013; 43: 163-9. 